\title{
Clara Schumann and Jenny Lind in 1850
}

J YOUNG KIM, ITHACA/NEW YORK

On March 20, 1850, near the end of Clara and Robert Schumann's north-German concert tour, the celebrated Swedish soprano Jenny Lind (figure 1) showed up unannounced at their door in Hamburg. To be fair, she was not completely unannounced: Robert had sent her a letter four days earlier, hoping for a meeting in Hamburg or Berlin, the Schumanns' next destination and where Lind was at the moment. But there was no reply from her, and hence no such plan made, when she suddenly arrived.

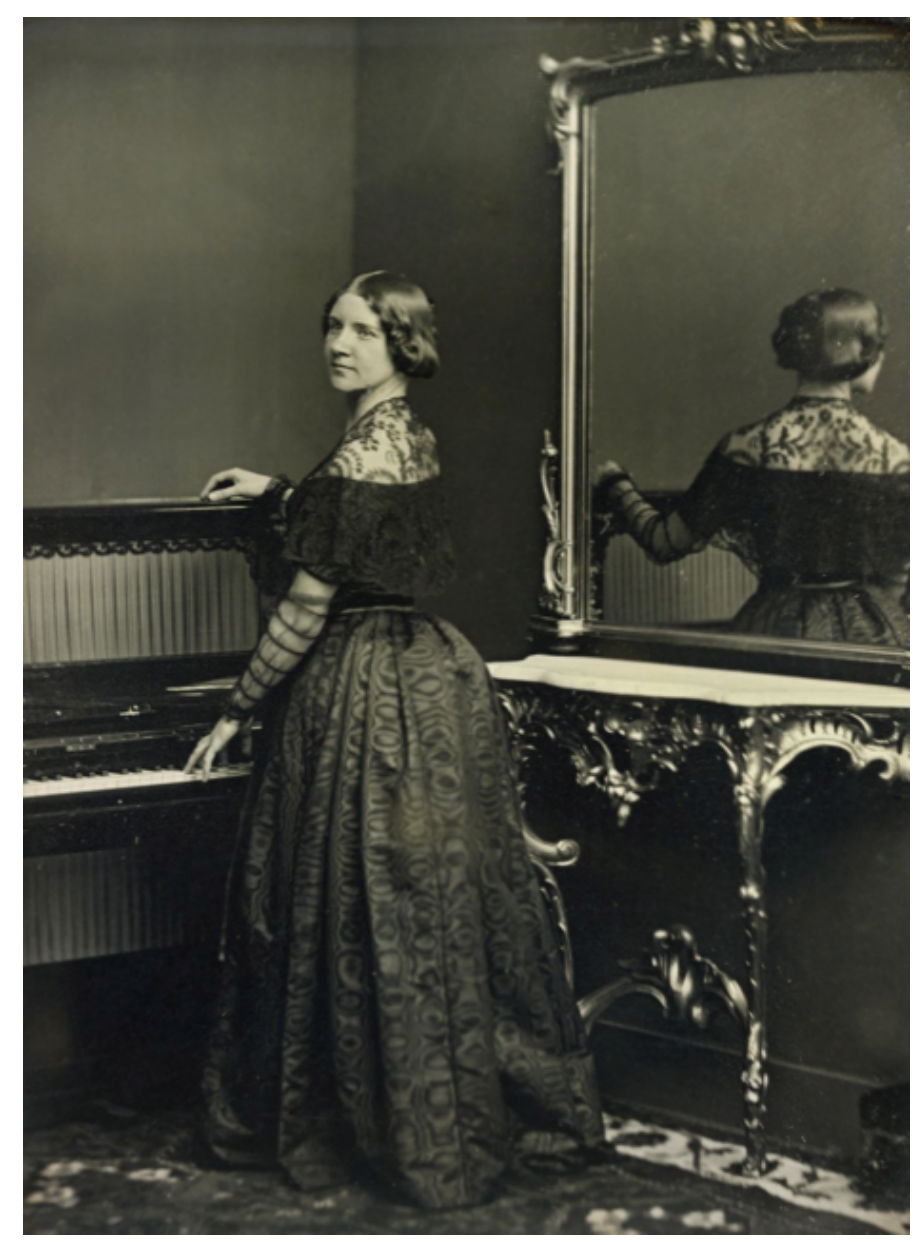

Figure 1: Daguerreotype of Jenny Lind by William Edward Kilburn (1848).

Lind claimed to have made the trip from Berlin in order to sing in one of the Schumanns' concerts before they left Hamburg. This was not the first time that she had spontaneously offered 
to take part in their performances. Three years earlier, in 1847, she had "come to the rescue" of the couple's disappointing series in Vienna by appearing in the final concert - a bittersweet moment in Clara's career, as critics pinned the concert's success on Lind's star power rather than the Schumanns' musical efforts. ${ }^{1}$ That experience would loom in the background for Clara as she collaborated with the soprano again three years later.

As it turned out, Lind sang in two of their upcoming performances: one was in Altona and already part of the Schumanns' schedule; the other was added at the last minute and took place in Hamburg. My starting point in this paper is an excerpt from Clara's diary (as quoted in Berthold Litzmann's biography) about this second, added performance, a matinee event in Hamburg's Apollo-Saal. It will be helpful for us to reproduce this entry at length here:

„Jenny Lind hatte sich hinter den Deckel des Pianoforte gesetzt, wobei eine allgemeine Bewegung entstand, denn wenige nur konnten sie nun sehen, und doch hätte sie gern jeder gesehen. Sie sang wieder wundervoll, Mozarts Arie aus Figaro mit einer hinreißenden Einfachheit (da hätte Frl. Wagner lernen können Respekt vor dem Komponisten), desgl. Lieder von Mendelsohn und vier Lieder vom Robert, natürlich wieder den Sonnenschein zum Schluß zweimal. Ein Beweis, wie sie alles, was sie singt, in sich aufgenommen gab sie heute wieder, indem sie, als beim Umblättern der Frühlingsnacht die Blätter verlegt waren, dieselbe auswendig zu Ende sang. Die Lieder von Robert sang sie alle so, wie ich sie mir immer in meinem Ideale gedacht, aber zu hören nie geglaubt hatte. Keine Feinheit, an der andre spurlos vorübergleiten, bleibt ihr verborgen, so auch wenn sie andre Musik hört, ist es ein wahres Vergnügen, ihr zuzusehen, wie auch nichts, nicht die zarteste, feinste harmonische Wendung ihr entgeht. - Ich spielte auch heute wieder gut, wie selten, was bei solch einer Begeisterung, wie dies Wesen in einen bringt, wohl kein Wunder! Auch hier nahm mich das Publikum mit gleichem Enthusiasmus auf, und ein Lied von Mendelssohn mußte ich wiederholen"².

For his part, Robert summarized the concert with his by this time characteristic terseness: "Um 2 Uhr Matinee im Apollosaal - die L.[ind] als Hörerin - ,der Sonnenschein"'." I will return to the overlap between their diary entries, particularly to the image of Lind as listener, later on. My broader aim is to increase our awareness of the many variables involved in the performance practice of Lieder during the $19^{\text {th }}$ century by reconstructing and reimagining the scene in Clara's entry. My paper does not an attempt to present an airtight argument or interpretation of this event; rather, it is an invitation to expand our lines of inquiry with regards to the Lied as cultural practice. Through this exercise, I will additionally draw observations about the musical personalities involved and their interaction.

On the surface, Clara's entry does not seem out of the ordinary, beyond perhaps the effusive, bordering on hagiographic, tone of her praise for Lind. (We should recall that Lind was not one of her regular singing partners, the way Amalie Joachim and Julius Stockhausen were

1 This episode is related in Berthold Litzmann, Clara Schumann: Ein Künstlerleben nach Tagebüchern und Briefen, vol. 2, Leipzig 1905, pp. 146ff. See also Robert Schumann: Tagebücher, ed. Gerd Nauhaus, vol. 2, Leipzig 1987, p. 411, as well as p. 413 and n. 729.

2 Litzmann, Clara Schumann, vol. 2, pp. $211 \mathrm{f}$.

3 Robert Schumann: Tagebücher, vol. 3, p. 522. 
to become later.) Yet details scattered here and there raise intriguing questions. Take, for instance, her seemingly casual and self-evident mention of the lid, "der Deckel des Pianoforte". This piece of equipment in the grand piano's construction typically goes unremarked in written historical documents like diaries, letters, and concert reviews. But as any modern pianist who has played with other singers or instrumentalists will admit, the lid has in recent times become an object of contention, of charged negotiation. Who has not engaged in a tug of war about whether to deploy the full prop stick or the short prop stick on a modern grand while accompanying? Accompanying - the activity thematized in this conference's title - is itself a word that has begun to elicit discomfort, and music conservatory programs in the United States and elsewhere have started to replace it with the more agency-endowed "collaborative piano"; a matter of semantics, perhaps, but one that encapsulates latent power dynamics between pianist and co-performer.

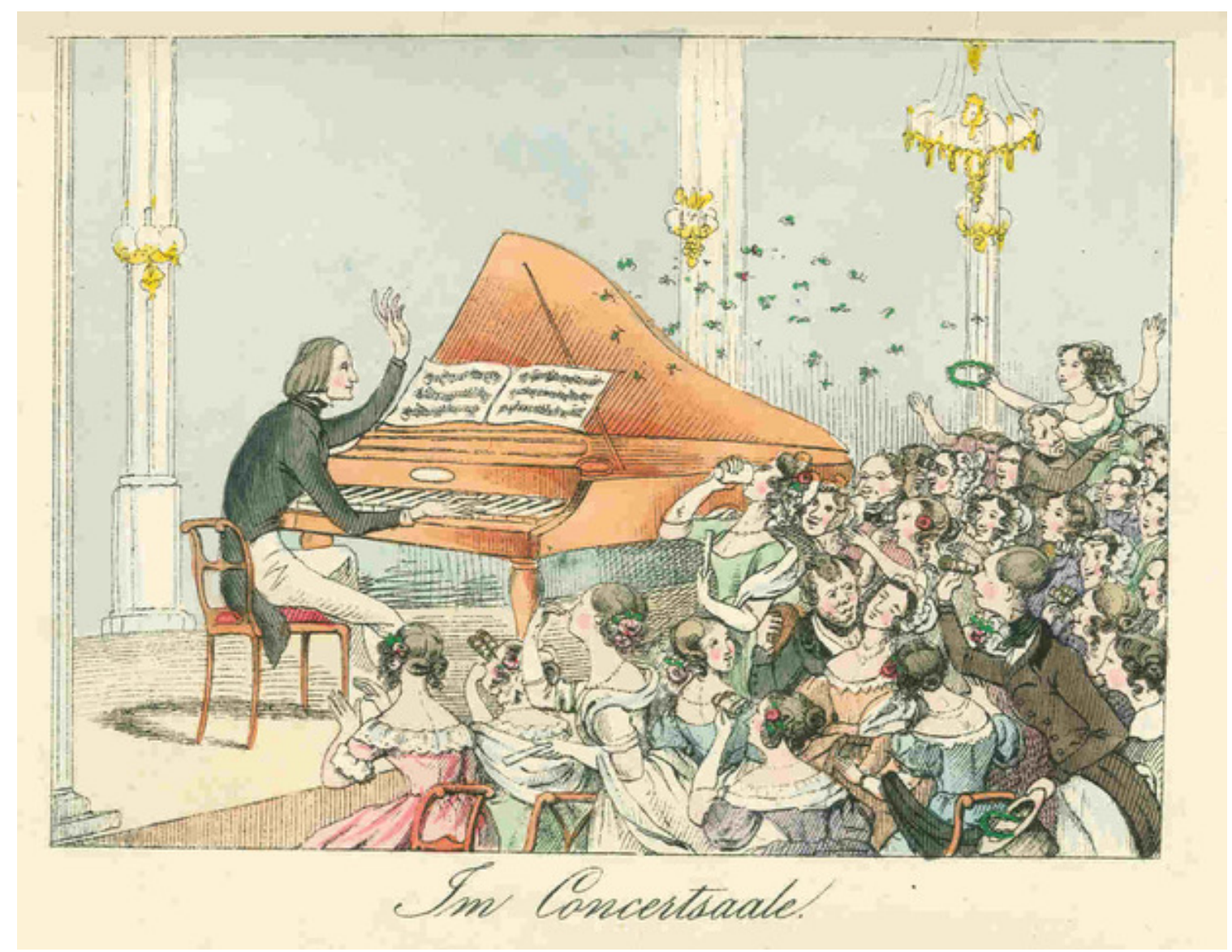

Figure 2: Caricature of a performance by Franz Liszt. From A. Brennglas [Glaßbrenner], Franz Liszt in Berlin: Eine Komödie in drei Akten (=Berlin wie es ist und-trinkt 14), Leipzig 1842.

While the discussion between pianist and co-performer may revolve around using the full or short prop stick, rarely would a modern pianist seriously consider performing (that is, not just practicing) with the lid closed. Yet we pianists, even those of us who claim to be historically 
informed, tend to forget that by and large this is how pianos seem to have been played from the $18^{\text {th }}$ century until the early, possibly even mid, $19^{\text {th }}$ century. Alfons Huber has argued that evidence from iconography and the near absence of prop sticks in extant Viennese pianos through the early $19^{\text {th }}$ century strongly suggest that they were played mostly with the lid closed (unless a situation made it desirable to take it off completely or prop it against a wall). ${ }^{4}$ Music and art historian Florence Gétreau has reached a similar conclusion about pianos and pianists based in Paris during the period between 1815 and 1848, thus pushing the timeframe a bit later. ${ }^{5}$ Unsurprisingly, Liszt represents an exception and a trailblazer in her narrative. In this well-known caricature of a recital in Berlin from 1842 (figure 2), the lid becomes a dynamic object which amplifies not only the music's physical power, but also the visual energy transmitted by Liszt's airborne hand and received by the flower confetti from his mostly female fans. Yet he is also one of few pianists to have been portrayed in the act of public performance before the year 1848 and, as we know, his reception and media presence, so to speak, were colored by a dramatic flair. ${ }^{6}$ There are later examples of famous virtuosi performing with a closed lid when collaborating with others, such as Alexander Lebedev's painting of Anton Rubinstein playing with a string quartet at an all-male aristocratic soiree in St. Petersburg in about 1860 . This is also how a satiric London magazine depicts a performance by Clara Schumann and Joseph Joachim in 1881 (figure 3). To be sure, this image is not an attempt at completeness and accuracy, but a sketch; as a caricature, the artist who drew it would have deliberately exaggerated certain aspects while underplaying others for comic effect. Iconography is obviously not a reliable repository of evidence and there are many ad hoc factors that can shape a performance setup. ${ }^{7}$

4 Alfons Huber, „Deckelstützen und Schalldeckel an Hammerklavieren”, in: Studia organologica: Festschrift für John Henry van der Meer zu seinem fünfundsechzigsten Geburtstag (=Wissenschaftliche Beibände zum Anzeiger des Germanischen Nationalmuseums, vol. 6), Tutzing 1987, pp. 229-251. I should note here that I am thinking particularly of grand pianos intended for use in more nearly professional contexts than, say, the domestic square piano. To be sure, there is a vast range in between that cannot be easily classified into categories like "professional" and "domestic". Yet I make this distinction because prop sticks and "dust boards" (to be discussed shortly) became common for English square pianos considerably earlier. See Malcolm Cole, The Pianoforte in the Classical Era, Oxford 1998, pp. 78-79.

5 Florence Gétreau, "Ouvert ou fermé: Images du piano romantique (1815-1848)", in: Interpréter Chopin (=Les cahiers du Musée de la musique, vol. 8), ed. Jean-Jacques Eigeldinger, Paris 2006, pp. 71-79.

6 Following my presentation at the conference, Ulrike Roesler kindly brought to my attention that Liszt appears to have been flexible and experimental with his performance setup, making adjustments according to the instrument and space at hand.

7 Thomas Synofzik generously shared with me an instance of a performance by Clara Schumann where the performers' position and the use of the lid struck a reviewer sufficiently to merit comment. The concert took place at the Gesellschaft der Musikfreunde on January 7, 1866, and the piece in question is Robert Schumann's Piano Trio in F major, Op. 80. The reviewer declared: „Das Schumann'sche Trio (Nr. 2) mißglückte heute in seinem ersten Theile; kein Wunder, wenn die einzelnen Spieler ganz isolirt, wenn die Herren mit den Bogen der Dame im Rücken sitzen... Daß der Deckel des prächtigen Streicher'schen Flügels nicht ganz abgehoben war, beeinträchtigte die Wirkung desselben nach mancher Seite". Wiener Zeitung 26 (January 31, 1866), p. 325. It remains unclear what "nicht ganz abgehoben" means in this context. At any rate, the review is interesting in that, for a fleeting moment, it spotlights the effect of the performers' positions vis-à-vis one another in chamber music. There is even an undertone of gender etiquette implied in his comment. I thank Dr. Synofzik for bringing this review to my attention. 


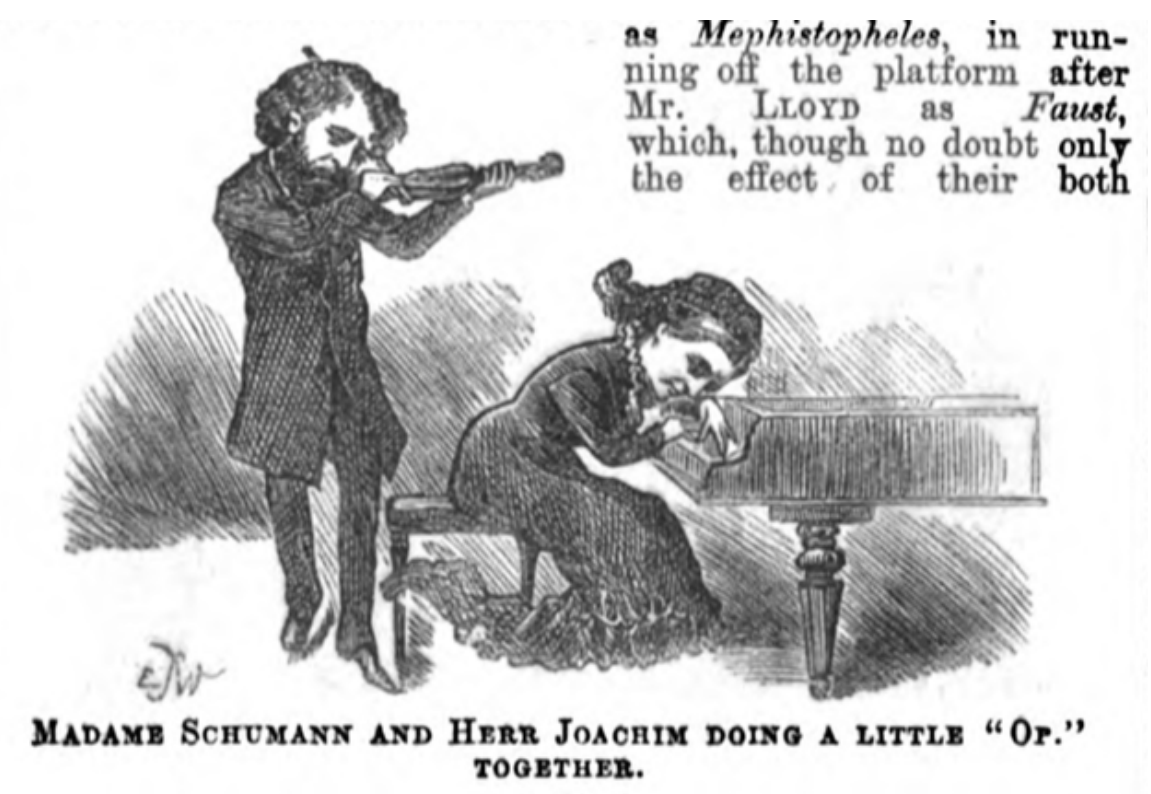

Figure 3: Caricature of a performance by Clara Schumann and Joseph Joachim. From Punch, or the London Charivari (March 19, 1881), p. 121.

Clara's mention of Jenny Lind's being behind the lid implies that on the occasion of their Hamburg matinee it was open, since it would have been odd for her to remark that the lid obstructed the audience's view of the singer had it been closed. Performing with an open lid was no longer rare by 1850 . But even in the case of pianos that did feature prop sticks, there remains another piece of equipment to be considered: the so-called "Schalldeckel". Many $19^{\text {th }}$ century pianos featured an extra, thinner lid, sitting above the strings and underneath the "actual" lid. The Graf piano given to Clara in 1838 possessed one at some point, ${ }^{8}$ and there are extant pianos by Streicher, Erard and Pleyel from the 1840s which also have it (figure 4). Thus non-Viennese builders likewise installed something similar in many of their instruments. Its purpose continues to mystify scholars of organology and performance practice, as well as builders and restorers of historical pianos. This has not prevented them from offering hypotheses which have ranged from practical uses (as protective dust covers), to cultural values (to cover up the piano's "uncouth" inner workings), to musical preferences. ${ }^{9}$ For example, the sound of an open piano may have proved too direct for people who were accustomed to the closed-lid aesthetic (though it must have added to the thrill and physical potency of Liszt's recitals), or the Schalldeckel may have been used for more intimate spaces and contexts, such as for the performance of Lieder. The specific acoustic repercussions remain contested and, to my knowledge, the implications for performance of these relics in historical pianos have not yet been analyzed. ${ }^{10}$

8 Huber, „Deckelstützen und Schalldeckel”, p. 250, n. 18, and Deborah Wythe, Conrad Graf (1782-1851): Imperial Royal Court Fortepiano Maker in Vienna, PhD diss., New York University, 1990, p. 560.

9 See again the Huber and Cole sources cited in n. 4.

10 With regards to the acoustic repercussions of the Schalldeckel, Huber remarks: „Wie mir bestätigt wurde, wird 


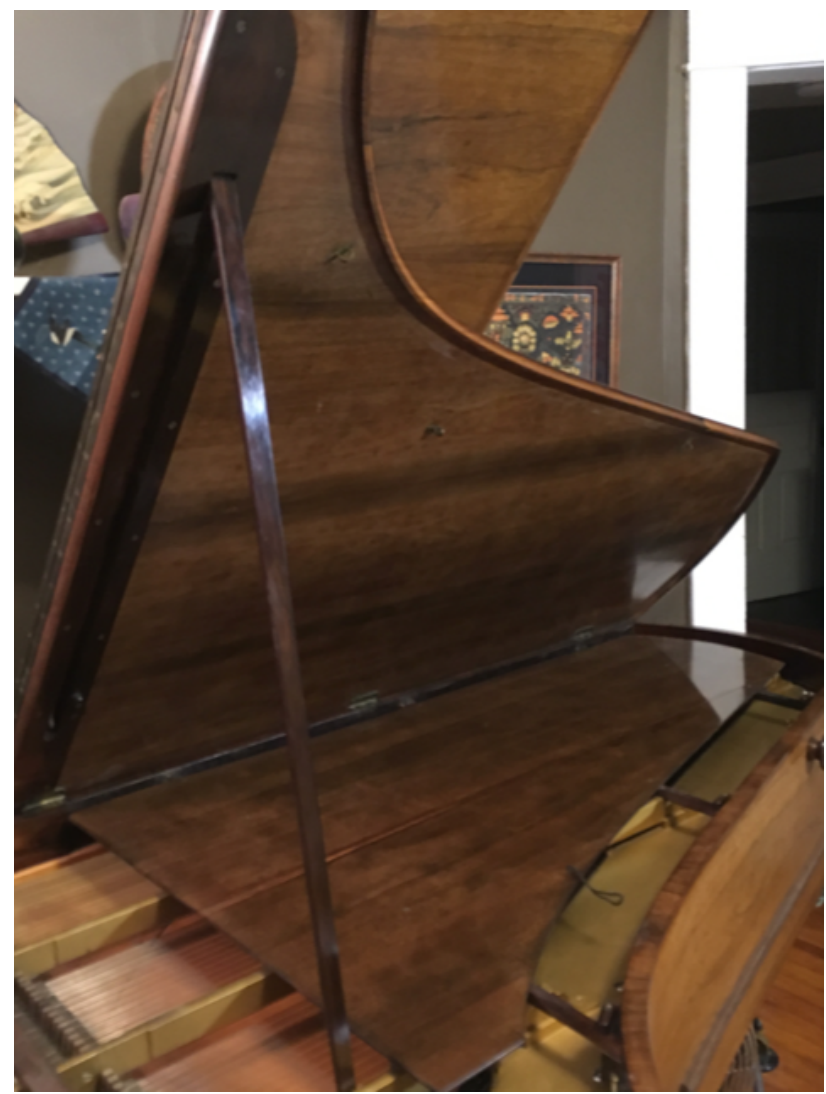

Figure 4: The inner lid in a Pleyel piano from 1848 or 1849. I thank Andrew Willis for this photo of his beautiful piano.

I don't purport to know Clara Schumann's exact piano setup at her concert with Jenny Lind. But her diary entry struck me like an old photograph, where a detail captured in the background as if by accident prompts one to wonder about habits of the past. Her passing reference to the lid is an indirect reminder that historical uses of the lid and Schalldeckel could upend our contemporary notions of timbre and balance, whether they be "modern" or "historically informed". In the realm of Lieder, specifically, a consideration of these instrumental variables could inform our knowledge of a genre whose roots were in intimate domestic music-making yet became increasingly part of concert repertoire over the course of the $19^{\text {th }}$ century. They could introduce new and tangible layers to Jennifer Ronyak's recent efforts to recover a more lyrical, less dramatic approach to the Lied, sensitizing us to the tension between the inward orientation of the genre and the outward pressures of performance. As she notes,

das Instrument durch den Schalldeckel nur unerheblich leiser. Der Deckel dunkelt als Obertonfilter allzu grelle Klangfarben ab, das Instrument wirkt grundtöniger, ohne so obertonarm zu werden wie das moderne Klavier mit seinen filzüberzogenen Hämmern" (p. 239). The one original piano in good condition possessing a Schalldeckel I have played is a restored Graf from 1839. While this was many years ago, Huber's description resonates with my personal recollection, but a more systematic study would of course be necessary in order to draw any conclusions. 
„performances of Lieder put pressure on the sense of interiority already ostensibly inscribed in the performed songs. [...] Expressing interiority outwardly via performance (i.e., what I will call intimate expression) threatened to leave the essential interiority of a poet, a song, or a performer unguarded and trampled on". ${ }^{11}$

Experimenting with the timbral variations afforded by the lid, Schalldeckel, and the position of the singer vis-à-vis the piano can be cues to explore this spectrum between private and public, lyric and dramatic, inward and outward.

In my own overenthusiasm as a historically-informed performer, I entertained the perhaps unlikely possibility that Jenny Lind actually sang behind the piano lid. Such a scenario could have had fascinating consequences along the lines just mentioned. Lieder could become private utterances quite literally, the vocal persona protected by the cover of the lid and nestled in intimate relation with the piano part. Had Lind performed in this setup, she would have in a sense used the lid as her own sort of Schalldeckel and thereby reinforced (or aggravated) existing characterizations of her voice. She was not known for possessing a loud voice, and it created the impression of disembodiment, as if it came from a source other than her body. Her highly popular renditions of the so-called Norwegian echo song thrived precisely on her ability to approximate pseudo-acousmatic, ventriloquized sounds. ${ }^{12} \mathrm{~A}$ critic for The Spectator reported in 1847 that her voice was "as etherial [sic] as the sighing of a breeze [and yet] reached... every part of the immense theatre", ${ }^{13}$ an opinion that is remarkably close to Clara Schumann's own. In 1850, she described her as "in jeder Hinsicht ein aetherisches Wesen" and, after hearing her for the first time in 1846, she wrote: "Ihre Stimme ist an sich nicht groß, dringt aber sicherlich in jedem Raume durch, weil sie ganz Seele ist" ${ }^{14}$ Her voice's limited volume and power somehow combined with a capacity to penetrate, such that it was equated with - or at the very least appeared to be compensated by - interiority, soulfulness, and depth.

Lind's high register was especially celebrated, whereas her middle and lower registers were described as "veiled". ${ }^{15}$ It is indeed remarkable how routinely this characterization appears. Consider the following examples:

11 Jennifer Ronyak, Intimacy, Performance, and the Lied in the Early Nineteenth Century, Bloomington 2018, p. 2.

12 Francesca Vella, "Jenny Lind, Voice, Celebrity", in: Music and Letters 98 (2017), no. 2, p. 239. This song, in which Lind often self-accompanied, is transcribed in the musical appendix to William Smyth Rockstro, $A$ Record and Analysis of the "Method" of the Late Madame Jenny Lind-Goldschmidt, London 1894. An annotation (by either Rockstro or the appendix's editor, Otto Goldschmidt) explains that in the mostly unaccompanied coda "Madame Goldschmidt turned from the Pianoforte towards the audience, facing it, and singing straight towards the length of the Room (having in view the production of the Echo) until the final notes, when she slowly turned back towards the Pianoforte, and struck the chord of D to the same note in the voice part" (p. xxvvii, emphasis original). Rockstro remarks that "the effect produced so nearly resembled that of a natural echo, reverberated from the opposite wall, that it never failed to mystify an audience before which it was presented for the first time" (p. 12). This anecdote about her performance, if true, betrays a savvy manipulation of space.

13 Unnamed critic, The Spectator (May 8, 1847), p. 443. Quoted in Vella, „Jenny Lind, Voice, Celebrity”, p. 239 , n. 40. For more reviews that reinforced the same point, see p. 246, n. 73.

14 Litzmann, Clara Schumann: Ein Künstlerleben, vol. 2, pp. 211 and 115, respectively.

15 Rockstro specifically ascribes the "veiled" timbre to $f^{\prime}-a^{\prime}$ in the middle register and believes its cause to be vocal injuries early in Lind's career. See Rockstro, A Record, pp. 10-11. 
„Mag vielleicht Mancher einen grösseren Umfang ihrer Stimme nach der Tiefe zu vermissen, ein Anderer den eigenthümlichen Flor, der die mittleren und tieferen Töne umschleiert, einen Fehler des Organes, einen Mangel an Egalität nennen [...] Jener Schleier aber, der um die mittleren Chorden gleich leichten Wolken schwebt [...] Gerade jener Duft, der sich dort um die Stimme legt, verleiht dem Gesang den geheimnissvollen, poetischen Zauber, der, nachdem das Ohr den Ton kaum erfasst hat, auch schon das Herz trifft". ${ }^{16}$

Clara again echoed this trope when she wistfully remarked upon hearing Lind decades later on February 22, 1871, as a 50-year old: „Die Stimme ist ja fast fort, aber doch in manchen Tönen noch der etwas verschleierte Timbre, und ein Liebreiz, eine Innerlichkeit, die unbeschreiblich ist". ${ }^{17}$ An unnamed critic in the London journal Frazer's Magazine for Town and Country, however, quoted and partially concurred with a more critical view of the same vocal quality: "The whole of the under register of her voice is, as her admirers express it, veiled; but I cannot refrain from describing this impenetrable veil as an intolerable hoarseness". ${ }^{18}$ The consistency of the vocabulary used to describe Lind may well register the wide circulation of a relatively small number of sources, but what I wish to emphasize is the implication of these comments. From opera casting to popular songs, voice types have come to be strongly associated with particular characters. Following these conventions, Lind's strength in the higher register became mapped onto performances of innocence, virginity, and childlike wisdom. But what is more remarkable in these quotes is how using the word "veiled" reframed her middle and lower registers. Typically, these are registers which evoke corporeality and older, more sultry characters. By slapping on a word redolent of feminine modesty and mystery, however, what could have been considered a weakness in Lind's vocal ability was instead celebrated as a sign of vague poeticism and interiority.

To return to our matinee in Hamburg, the truth is that we don't know at what point Lind stood or sat behind the lid. The concert program was as follows:

- R. Schumann: Piano Quintet, Op. 44 („auf Verlangen“)

- Mozart: Aria from The Marriage of Figaro

- Beethoven: Piano Sonata, Op. 57

- F. Mendelssohn: 2 Lieder (among them "Rheinisches Volkslied")

- Chopin: Nocturne in $\mathrm{C}$ minor

- F. Mendelssohn: Lied ohne Worte in C major

16 [L. R.], „Nachrichten”, Allgemeine musikalische Zeitung 47 (December 10, 1845), no. 50, pp. 892-893. Emphasis mine.

17 Litzmann, Clara Schumann: Ein Künstlerleben, vol. 3, p. 254. Emphasis mine.

18 [Anonymous], "Prospects of the Opera“, Frazer's Magazine for Town and Country 37 (1848), p. 339. The author here cites an unnamed Berlin critic and then adds: „Her hoarseness was frequently observed during the last season, and the care with which she shunned notes which lay even moderately below the treble staff was obvious. In the little song, ,Deh vieni', in Mozart's Figaro, she was obliged to alter the notes of the original to avoid touching middle $C_{\text {; }}$ though her general conception of the air was so fine in its simplicity and tenderness as to create a breathless interest in the house". 
- R. Schumann: „Der Himmel hat eine Thräne geweint", „Der Nußbaum“, „Frühlingsnacht", „O Sonnenschein"19

She may have been in that position during the Piano Quintet, which opened the concert and preceded her first solo; she may have then stood by the bass end of the piano (the way violinpiano duos were in the $18^{\text {th }}$ century) or in front of the piano (as is now the custom) to sing the Mozart aria. ${ }^{20}$ While the mention of the lid raises tantalizing questions about performance practice, ultimately, its effects, at least as registered in Clara's entry, are not sonic but visual. Lind's position caused a general commotion whereupon audience members struggled to catch a glimpse of her. This gesture, which drew Clara's attention sufficiently to write it down, was part of a pattern of behavior that fed her brand of feminine modesty. After the two women first met in 1846, for example, Clara wrote in her diary: „Hier gewann ich Jenny Lind doppelt lieb durch ihr anspruchloses, ich möchte fast sagen, zurückhaltendes Wesen; man merkte kaum, daß sie da war, so still war sie". ${ }^{21}$ Thus she looked at her fellow woman's self-effacement with approval.

Intentionally or not, Lind appears to have used the lid in an unusual way at the Hamburg concert, as a prop which allowed her to escape the searching (and maybe invasive) gaze of the audience by retreating behind it; indeed, by deploying it as a kind of "veil", even if only momentarily.

But of course, this act only intensified the desire to see her. Interestingly, the audience's occluded view contrasts with Clara's own, conspicuously visual experience of Lind at this concert. Let us recall again what she wrote in her diary about it: „Wenn sie andre Musik hört, ist es ein wahres Vergnügen, ihr zuzusehen, wie auch nichts, nicht die zarteste, feinste harmonische

19 Concert program no. 283 on March 23, 1850, at the Apollo-Saal, Hamburg, as given in Robert Schumann Tagebücher, vol. 3, pp. 783-784, n. 750 .

20 There is scant information about the Apollo-Saal before it was expanded in 1853 to supplement our reconstruction of this scene. Sonja Esmyer estimates that the oval space's approximate dimensions were 24 meters long and 15 meters wide, with a ceiling 9 meters high. A caveat in her estimation is the lack of standardized measurements in Germany at the time. See Sonja Esmyer, Hamburger Konzertstätten von der Mitte des 18. bis Anfang des 20. Jahrhunderts vor dem Hintergrund der Entwicklung des öffentlichen Hamburger Konzertwesens, M.A. thesis, University of Lüneburg 1996, p. 34.

21 Litzmann, Clara Schumann: Ein Künstlerleben, vol. 2, p. 115. One could say that her selection of Lieder for the Hamburg matinee reinforced her image of modesty and innocence. Mendelssohn's "Rheinisches Volkslied" sings of desire, but cast in a scene amid children; in the songs by Robert Schumann desire is expressed indirectly or refracted through nature. None of these pieces involve first-person expression of intense feeling. (Someone like Wilhelmine Schroeder-Devrient, by contrast, made Frauenliebe und Leben a core of her repertoire.) As is well known, P. T. Barnum seized upon this aspect of Lind's profile as he launched an aggressive marketing campaign for her tour of the United States, which was to begin in September 1850, just months after the Hamburg concert. The New York Tribune reported after her first appearance: „JENNY LIND, clad in a white dress which well became the frank sincerity of her face [...] The divine songstress, with that perfect bearing, that air of all dignity and sweetness, blending a child-like simplicity and half-trembling womanly modesty with the beautiful confidence of Genius and serene wisdom of Art, addressed herself to song". Quoted in Mark Samples, "The Humbug and the Nightingale: P. T. Barnum, Jenny Lind, and the Branding of a Star Singer for American Reception", in: The Musical Quarterly 99 (2016), nos. 3-4 ,p. 306. 
Wendung ihr entgeht". ${ }^{22}$ This excerpt betrays a feeling of proximity, as if, even in portions of the program when Clara was not accompanying Lind, she could see her from her direct or peripheral visual field as she played - more than that, it is as if she could not restrain herself from watching her. (The program being as given above, it is clear that when she refers to "andre Musik", she is referring to her own playing.) Robert, who was in the audience and not performing at this concert, likewise responded to Lind's listening stance, indeed, at the expense of commenting on her singing or Clara's playing. The overlap between Clara and Robert's diary entries may well bespeak post-concert conversations. But it also raises the question of who is leading, the performer, or the listener? The boundaries between what is and what is not performance become blurred in Lind's presence, as her listening behavior appears to be something to be beheld. Listening here is performed, it becomes visible to others.

The soprano's demeanor in turn spurs Clara's playing: "Ich spielte auch heute wieder gut, wie selten, was bei solch einer Begeisterung, wie dies Wesen in einen bringt, wohl kein Wunder!" A sort of channel appears to have opened up between these three figures - Lind, Clara, and Robert - an exclusive channel where only "true" artists can recognize each other. What else did Clara see that the audience could not? Well, for one thing, if we revisit Clara's diary entry, she saw Lind sing Lieder from memory. As a pianist who made it an integral part of her profile to play from memory, she was duly impressed when the soprano continued to sing "Frühlingsnacht" from memory after a misplaced page. For her this was evidence of deep musical internalization, and Lind's persona resonated with her own artistic values. While the Werktreue ideology has often become Clara's mantle (or burden) to bear, among singers Lind too was recognized for sharing that attitude. A critic for the Allgemeine musikalische Zeitung observed as early as 1845 :

„Was sie aber in meinen Augen noch besonders hoch stellt, ist das, dass sie ihr ganzes Kunstvermögen dazu anwendet, in die Intentionen des Tondichters einzudringen und diese allein wiederzugeben, nie aber die selbst bei den ersten und genialsten Bühnenkünstler häufig bemerkbare Schwäche zeigt, das eigene Ich zum Nachttheile der Tondichtung oder des Ganzen glänzen zu lassen"..23

She may have been a model for Clara's developing profile as it crystallized into Liszt's 1854 description of her as a "priestess of the Delphian god". More generally, this may have been one of the few ways women could chart a powerful image of themselves that did not objectify them and gained them respect.

I began this presentation by drawing attention to the piano lid. If indeed performing with it open was a Lisztian, virtuoso kind of gesture that had only recently and gradually become commonplace, Clara's accompanying of Lind in this way presented her as a soloist not to be outdone by the Swedish star. We know from her diary that she was apprehensive about sharing the stage with her, likely because of her experience performing with the singer in Vienna back

22 See n. 2 above.

23 [Anonymous], Allgemeine musikalische Zeitung 47 (September 24, 1845), no. 39, p. 662. 
in $1847 .{ }^{24}$ For her part, Lind used precisely the open lid as a means of self-effacement by being behind it, yet in the act increased the attention to herself. Through this and other gestures of modesty, she gained Clara's own, female admiration, while prying open conflicting forces in her performance persona.

At this point, it will surely come as a disappointment to my reader that, in spite of all the information I have laid out in this paper, we barely seem to have come closer to understanding Clara Schumann's performance practices as vocal accompanist. This is, in part, inevitable because there is such meager documentation about it. In her own accounts of her playing, she appears to become invisible when it comes to vocal accompanying; while she is ready to commend or critique her partner's singing, when she mentions her own playing it tends to refer to her solo playing. Thus, the closest we can get appears to be what we have got here: the pianist's furtive glances at the singer she accompanies.

Zitation: Ji Young Kim, "Clara Schumann and Jenny Lind in 1850", in: Die Begleiterin - Clara Schumann, Lied und Liedinterpretation, hrsg. von Rebecca Grotjahn und Nina Jaeschke (= Musikwissenschaft: Aktuelle Perspektiven. Bericht über die Jahrestagung der Gesellschaft für Musikforschung 2019 in Paderborn und Detmold, Bd. 2), Detmold 2020, S. 85-96, DOI: 10.25366/2020.85.

24 After the Altona concert on March 21, 1850, just before the matinee in Hamburg, she wrote candidly: "Ich war sehr glücklich, auch dadurch, daß ich dem Publikum gegenüber als Künstlerin nicht gegen die Lind zurückstand, sondern gleiches Interesse und gleichen enthusiastischen Beifall fand als sie. [...] Ich hatte mich sehr vor dem demütigenden Gefühle einer Zurücksetzung gefürchtet, und daß es nun nicht so war, freute mich sehr!" Litzmann, Clara Schumann: Ein Künstlerleben, vol. 2, p. 209. 


\section{Abstract}

Clara Schumann's 1850 tour of northern Germany with her husband officially ended with a successful concert in Altona where Jenny Lind made a surprise appearance. Immediately thereafter, one more concert featuring the pianist, singer, and Robert's music was added at the last minute to take place in Hamburg. This too was a success. But a detail that made it especially memorable was Lind's position behind the piano lid so that, as Clara recounted in her diary, many audience members could hardly catch a glimpse of her. This paper explores the rationales and implications of this singular and fleeting moment, and teases out aspects of the two star performers' relationship both on and off the stage. In the process, the paper draws attention to hitherto neglected variables in the performance practice of Lieder and seeks to expand our lines of inquiry with regards to the $19^{\text {th }}$-century Lied as cultural practice.

\section{Vita}

Ji Young Kim is a musicologist, fortepianist, and educator focusing on musical cultures of the late 18th and 19th centuries. She obtained her PhD in musicology in 2019 from Cornell University with a dissertation titled "Innere Stimmen and Hidden Duets in the Piano Music of Robert Schumann and Johannes Brahms". 
Die Begleiterin

Clara Schumann

Lied und Liedinterpretation

Herausgegeben von Rebecca Grotjahn und Nina Jaeschke

Musikwissenschaft: Aktuelle Perspektiven 2 
Die Begleiterin 


\section{Musikwissenschaft: Aktuelle Perspektiven}

Bericht über die Jahrestagung der Gesellschaft für Musikforschung 2019 in Paderborn und Detmold

Herausgegeben von Rebecca Grotjahn und Nina Jaeschke

Band 2 


\section{Die Begleiterin \\ Clara Schumann, Lied und Lied- interpretation}

Herausgegeben von Rebecca Grotjahn und Nina Jaeschke

Detmold: Musikwissenschaftliches Seminar der Universität Paderborn und der Hochschule für Musik Detmold 2020 
DOI: $10.25366 / 2020.78$

Online-Version verfügbar unter der Lizenz: Urheberrecht 1.0, $<$ https://rightsstatements.org/page/InC/1.0/?language=de>

Bibliografische Information der Deutschen Nationalbibliothek

Die Deutsche Nationalbibliothek verzeichnet diese Publikation in der Deutschen Nationalbibliografie; detaillierte bibliografische Daten sind im Internet über http://dnb.d-nb.de abrufbar.

\section{Impressum}

Redaktion: Nina Jaeschke, Rebecca Grotjahn und Jonas Spieker Satz: Nina Jaeschke

(C) Musikwissenschaftliches Seminar der Universität Paderborn und der Hochschule für Musik Detmold 2020 


\section{INHALT}

Vorwort $\quad$ VII

Rebecca Grotjahn

Einleitung 1

\section{Beatrix Borchard}

„Frau Klara Schumann der besten Sängerin."

\section{Thomas Synofzik}

"Würde Sie's zu sehr ermüden zu begleiten?" -

Clara Schumann als Lied- und Kammermusikpartnerin

\section{Annegret Huber}

Die Pianistin spricht. Überlegungen zur Epistemologie von Vertonungsanalysen und ihrer Funktion in musikwissenschaftlicher Forschung

\section{Martin Günther}

Liedbegleitung und künstlerische Identität.

Zur Zusammenarbeit Clara Schumanns mit Julius Stockhausen

\section{Ji Young Kim}

Clara Schumann and Jenny Lind in 1850

\section{Kilian Sprau}

"Wozu die Mühe?"

Über Begleiterlizenzen und ihr Schwinden aus der Aufführungspraxis des Kunstlieds. Mit Tonträgeranalysen zu Richard Strauss, "Zueignung” op. 10 Nr. 1 
Gabriele Buschmeier in memoriam 


\section{Vorwort}

Die vorliegenden Bände dokumentieren die Jahrestagung der Gesellschaft für Musikforschung 2019. In den dreieinhalb Tagen vom 23. bis zum 26. September 2019 wurden in Paderborn und Detmold nicht weniger als 185 Beiträge präsentiert, verteilt auf diverse Symposien, Round tables, Freie Sektionen und Postersessions. Sie alle auf einen Nenner bringen zu wollen, ist ein Ding der Unmöglichkeit - und das ist gut so, ist es doch Ziel der Jahrestagungen, die große Vielfalt der Themen und Methoden des Faches Musikwissenschaft abzubilden. Um die thematische Vielfalt der freien Referate angemessen abbilden zu können und gleichzeitig den inhaltlichen Schwerpunkten der beiden hier publizierten Hauptsymposien ausreichend Raum bieten zu können, erscheinen diese in drei Bänden.

„Musikwissenschaft: Aktuelle Perspektiven": Der Titel der kleinen Reihe ist keine Verlegenheitslösung. Musikwissenschaft im Kontext der Digital Humanities; Musikwissenschaft und Feminismus; Musik und Medien; Musikalische Interpretation - schon die Felder, die von den vier Hauptsymposien bespielt wurden, wären noch vor wenigen Jahrzehnten allenfalls an der Peripherie das Faches zu finden gewesen. Sie entsprechen Arbeitsschwerpunkten der Lehrenden am Musikwissenschaftlichen Seminar der Universität Paderborn und der Hochschule für Musik Detmold, das die Tagung ausrichtete. Zugleich nehmen sie Bezug auf aktuelle Ereignisse und Entwicklungen. So erwuchs das von Andreas Münzmay und Joachim Veit organisierte Symposium „Brückenschläge - Informatik und Musikwissenschaft im Dialog" unmittelbar aus den Erfahrungen im Virtuellen Forschungsverbund Edirom (ViFE) und im fakultäten- und hochschulübergreifenden Zentrum Musik-Edition-Medien (ZenMEM). Der 200. Geburtstag von Clara Wieck/Schumann war der Anlass für das von Rebecca Grotjahn geleitete Symposium „Die Begleiterin - Clara Schumann, Lied und Liedinterpretation", das in enger Kooperation mit der Hochschule für Musik Detmold durchgeführt wurde. Das Hauptsymposium „Brückenschläge" wird in einem separaten Band publiziert (Bd. 3 der vorliegenden Reihe). Im Rahmen dieses Symposiums führte die von Stefanie Acquavella-Rauch geleitete Fachgruppe Digitale Musikwissenschaft eine Posterpräsentation durch, die von den Beiträger*innen erfreulicherweise zu kürzeren Texten umgearbeitet wurden, sodass sie hier ebenfalls, zusammen mit den Postern,

publiziert werden können. Hinzu kommen einige Beiträge, die bereits bei der Jahrestagung 2018 in Osnabrück präsentiert wurden. Auch das Hauptsymposium "Die Begleiterin" wird in einem eigenen Band (Bd. 2) publiziert. Die Beiträge zu den beiden anderen Hauptsymposien hingegen werden an anderen Orten veröffentlicht; in Band 1 („Freie Beiträge zur Jahrestagung der Gesellschaft für Musikforschung 2019") der vorliegenden Publikation finden sich jedoch Einführungen und Abstracts. Das Symposium „Komponieren für das Radio" unter Leitung von Antje Tumat und Camilla Bork (Katholieke Universiteit Leuven) behandelte Einflüsse des Mediums auf Kompositionsprozesse sowie durch radiophone Kompositionen bzw. radiophonen Klang ausgelöste Diskurse. Sarah Schauberger und Cornelia Bartsch (Universität Oldenburg) nahmen das 25-jährige Jubiläum der Fachgruppe Frauen- und Genderstudien zum Anlass für einen Generationenaustausch zum Thema "Musikwissenschaft - Feminismus - Kritik": Was wa- 
ren vor einem Vierteljahrhundert Inhalte und Aufgaben einer feministischen Musikwissenschaft und wie kann sich diese heute positionieren?

Bewusst haben wir im Tagungsbericht auf inhaltliche Eingriffe in die Beiträge verzichtet. ${ }^{1}$ Das gilt besonders für die Freien Referate: Es galt, den Charakter der Jahrestagung als Forum für ,freie', d. h. innovative und auch experimentelle Gedanken zu wahren. Einige Kolleg*innen, die die Tagung mit Vorträgen und Posterpräsentationen bereichert hatten, haben sich gegen eine Publikation im vorliegenden Band entschieden - sei es, weil sie eine Möglichkeit fanden, ihre Beiträge in einem inhaltlich passenderen Rahmen zu veröffentlichen, sei es, weil ihre Überlegungen in ihre entstehenden Qualifikationsschriften fließen sollen, oder sei es, weil sie von den Autor*innen in der vorgetragenen Form zunächst verworfen wurden. Auch damit erfüllt eine Freie-Referate-Sektion ihren Zweck: Die Diskussionen mit der versammelten Fach-Öffentlichkeit sollen dabei helfen, Gedanken weiterzuentwickeln und zu verändern. In diesem Sinne sei allen Beteiligten - den Autor*innen, den nichtpublizierenden Referent*innen und den Mit-Diskutant*innen - ganz herzlich gedankt für ihr Mitwirken bei der Tagung.

Unser herzlicher Dank gilt einer Reihe weiterer Personen, die zum Gelingen dieser drei Bände beigetragen haben. Hier ist besonders Jonas Spieker zu nennen, der uns tatkräftig bei der Redaktion geholfen hat. Andrea Hammes (SLUB Dresden) sei herzlich für die Aufnahme unseres Bandes auf musiconn.publish gedankt - wir freuen uns, damit unsererseits zur Etablierung dieser innovativen Publikationsplattform beizutragen.

Erneut möchten wir an dieser Stelle allen Menschen danken, die uns bei der Organisation, Ausrichtung und Finanzierung der Tagung selbst unterstützt haben: der Präsidentin der Universität Paderborn, Prof. Dr. Birgitt Riegraf, dem Rektor der Hochschule für Musik Detmold, Prof. Dr. Thomas Grosse, den Kolleginnen und Kollegen der beiden beteiligten Hochschulen, dem Vorstand der Gesellschaft für Musikforschung, der Universitätsgesellschaft Paderborn und allen Sponsoren. Besonders dankbar sind wir den Mitarbeiter*innen und den studentischen bzw. wissenschaftlichen Hilfskräften des Musikwissenschaftlichen Seminars, die bei der Vorbereitung und Ausrichtung der Tagung immensen Einsatz zeigten - stellvertretend sei an dieser Stelle Johanna Imm erwähnt, die zusammen mit Nina Jaeschke das Herz des Organisationsteams bildete.

Wir widmen diese Reihe Dr. Gabriele Buschmeier, dem langjährigen Vorstandsmitglied der Gesellschaft für Musikforschung, die kurz vor der Publikation dieses Bandes unerwartet verstarb.

Detmold, im September 2020

Rebecca Grotjahn und Nina Jaeschke

Zitation: Rebecca Grotjahn und Nina Jaeschke, "Vorwort”, in: Die Begleiterin - Clara Schumann, Lied und Liedinterpretation, hrsg. von Rebecca Grotjahn und Nina Jaeschke (= Musikwissenschaft: Aktuelle Perspektiven. Bericht über die Jahrestagung der Gesellschaft für Musikforschung 2019 in Paderborn und Detmold, Bd. 2), Detmold 2020, S. VII-VIII, DOI: 10.25366/2020.79.

1 Freigestellt war den Autor*innen auch, ob sie sich für eine gendersensible Sprache entscheiden bzw. welche Form des Genderns sie bevorzugen. 